\title{
WORKFORCE HOUSING IN TEXAS, USA
}

\author{
SEAN GARRETSON \\ AICP, USA
}

ABSTRACT

The United States and Spain have a varied history in their efforts to provide and preserve affordable housing. While one of Spain's main housing issues is its dearth of rental housing, the United States is troubled by a significantly higher percentage of housing cost-burdened residents. In Spain, an estimated $10 \%$ of the total population was housing cost-burdened in 2013 (defined as paying over $40 \%$ of income on housing). In contrast, an alarming 37\% of US households were housing cost-burdened in 2017 (defined in as paying over $30 \%$ of income on housing). While the histories of housing policies and initiatives have differed greatly in both countries, historical and current trends demonstrate that there is still much to be done. This article examines housing policies in Spain and the United States, highlights progressive housing policies emerging from Austin, Texas and provides a case study of a workforce housing development in Austin, Texas. The reader will gain an understanding of how these policies, tools and developments could serve as an example for addressing Spain's housing crisis.

Keywords: workforce housing, affordable housing, housing policy, housing programs, housing cost-burden.

\section{INTRODUCTION}

Both Spain and the United States are facing an affordable/workforce housing crisis. While the histories of housing policies and initiatives have differed greatly in both countries, historical and current trends demonstrate that there is still much to be done. In Spain, an estimated $10 \%$ of the total population was housing cost-burdened in 2013 (defined as paying over $40 \%$ of income on housing). In contrast, an alarming $37 \%$ of US households were housing cost-burdened in 2017 (defined in as paying over 30\% of income on housing). The current levels of housing unaffordability in both nations calls into question the efficacy of past policies and demands new responses. On the brink of facing a local workforce housing crisis, Austin, Texas, has become a model for progressive affordable housing policies. Determined to correct the trajectory, the City of Austin has recently developed and implemented a wide range of affordable housing policies. This article explores the historical and recent housing policy responses in both Spain and United States, focusing on the newer policies emerging from Austin, Texas, and their potential applicability within Spain.

\section{A BRIEF HISTORY OF AFFORDABLE HOUSING POLICY IN THE UNITED STATES}

The United States has a varied history in its efforts to preserve and provide affordable housing. Since the 1930s, the federal government has tried both demand- and supply-side approaches, ranging from tax-credits for the provision of affordable housing to rental subsidies for low-income households. One of the first affordable housing policies was the National Housing Act of 1934, which created the Federal Housing Administration (FHA) [1]. While the FHA's responsibilities have expanded since, it was originally created to ensure the accessibility of home loans, in addition to regulating mortgage terms and interest rates. Shortly after, the United States Housing Act was passed in 1937, which created the United States Public Housing Authority (USPHA); the USPHA not only provided financing for affordable housing but was also responsible for the construction of publicly subsidized housing. In a move away from public housing, the Housing Acts of 1956 and 1961 
incentivized private developers to invest in affordable housing by providing mortgage rate subsidies and by lowering insurance rates. The historical trend has involved a shift from the federal government to private developers as the main suppliers of affordable housing [1].

\section{CURRENT AFFORDABLE HOUSING POLICIES: UNITED STATES}

Currently, there is a diverse range of affordable housing policies provided by Federal, State, and Local governments. There are three main types of policies: rental assistance, land use and regulatory incentives, and homeownership assistance. Two of the largest rental assistance programs are the Low-Income Housing Tax Credit (LIHTC) and the Housing Choice Voucher program (as known as Section 8). On the supply-side, the LIHTC incentivizes the production of affordable, rental housing by providing private sector developers with federal income tax credits. In exchange for the credits, developers are required to reserve a minimum number of units for low or very low-income residents, and these units must remain affordable for a minimum of 30 years [2]. According to the U.S Department of Housing and Urban Development (HUD), the LIHTC program provides state and local agencies with approximately $\$ 8$ billion annually for the rehabilitation, acquisition, or new construction of low-income rental housing. HUD estimates that an average of 107,000 units have been placed into service from 1995 to 2017 [2]. In contrast to supply-side approaches, the Housing Choice Voucher program provides a rental subsidy to low-income families for use in the private rental market. It is estimated that over two million households participate in the program [3].

Homeownership assistance and land use/regulatory incentives encompass the two other main affordable housing policy approaches. Homeownership assistance programs may offer low-interest mortgages to perspective homebuyers, subsidize the production of for-sale homes or provide down payment assistance. In contrast, land use and regulatory incentives focus on policies and programs which guide, incentivize, or require developers to build affordable housing. One such policy gaining traction in major cities is inclusionary zoning, which incentivizes (or requires) developers to set aside a certain number of units within new residential developments for low-income households. The efficacy of policies, such as inclusionary zoning, has varied greatly depending on implementation and whether the policies are mandatory or voluntary.

Down payment assistance for those buying a house is also something that employers and banks provide. The Community Reinvestment Act (CRA) created in 1977 is a federal law designed to encourage commercial banks and savings associations to help meet the needs of borrowers in all segments of their communities, including low- and moderate-income neighborhoods. By providing down payment assistance, banks obtain CRA. Banks are required to have a certain level of CRA before they can (1) sell their bank or (2) buy other banks. As such, banks are always looking for ways to increase the CRA credibility.

\section{AFFORDABLE HOUSING IN SPAIN}

Housing policy in Spain greatly prioritizes home ownership. Unsurprisingly, much of what Spain considers public (or social) housing is also owner occupied, which leads to one of its central affordable housing issues- the lack of affordable rental housing. Approximately $80 \%$ of Spaniards own their homes, with the remaining 20\% renting [4]. The decrease in rental housing over the past decades has only been exacerbated by the growth of vacation rentals, facilitated by companies such as Airbnb [5]. In order to curb this trend, various cities have undertaken controversial policies. Barcelona, for example, recently revived a policy to which allows the city to expropriate vacant, bank-owned properties and turn them into affordable housing rentals [6]. Beyond city initiatives, the Spanish government recently imposed rentsuppression measures, which limit annual rent increases to the inflation for 5 years [7]. 
The Spanish Constitution guarantees the right to housing. To this effect, social housing is subsidized by the State through low-interest loans for developers. In exchange, units must comply with stipulated conditions/standards and must be sold for prices below market value. Even with its strong stance on the right to housing, housing affordability continues to be a challenge in Spain. In 2013, an estimated 10\% of Spain's total population was housing cost burdened (paying at least $40 \%$ of disposable income on housing costs), this number jumps to $38 \%$ for those earning $60 \%$ or below the median household income [8].

\section{AUSTIN: THE NEXT SILICON VALLEY?}

In many ways, Austin is following a similar trajectory to Silicon Valley. Now home to the headquarters of Apple, Dell, Facebook, and IBM (to name a few), technology and innovation are fueling tremendous economic growth in Austin. What remains uncertain is if Austin will follow the same path as Silicon Valley in terms of housing. Silicon Valley now has the highest housing costs in the United States, with the median home sales price being \$1.2 million in 2018 [9]. While average incomes in Silicon Valley are significantly higher than the national average (approximately $\$ 118,000$, versus $\$ 60,336$ respectively) [10], [11], only $18 \%$ of households in the county can afford the median home price [12]. The situation for renters is equally dire, with $48.4 \%$ of all renters in the county paying over $30 \%$ of income on rent in 2017 [13].

While various challenges have exacerbated the affordable housing crisis in Silicon Valley, the dearth of new affordable housing units has been at the forefront. For example, 18 affordable housing units were approved in 2017 , making up only $8 \%$ of all new units approved [9]. The barriers to the provision of housing in Silicon Valley include lengthy development review, community opposition, and a lack of developer incentives. Considering the similarities between Austin and Silicon Valley, Austin must act swiftly to forge a more equitable housing trajectory, with its efficacy hinging on the ability of the local government to address the aforementioned barriers.

\section{AUSTIN: AFFORDABLE HOUSING, POLICY AND PROGRAMS}

Austin is growing at a tremendous pace- from 2000 to 2015 the city experienced a population growth of $20 \%$. However, this population growth has outpaced the production of affordable housing for the diverse range of incomes. To this effect, the percent of rental cost-burdened residents (paying over $30 \%$ of income on housing) also grew from $41 \%$ in 2000 to $48 \%$ in 2015 [14]. In an effort to address the issue of affordable housing, the City of Austin governmental body created several initiatives:

- $\quad$ The SMART housing policy (Safe, Mixed-income, Accessible, Reasonably priced and Transit-oriented), which was designed to encourage the provision of affordable housing for low- and moderate-income residents. The program allows for full or partial fee waivers and faster development review in exchange for a varying percentage of affordable housing [15]. This has been a good incentive, yet the City of Austin's staffing has not yet aligned with this policy, in terms of fast-track permitting.

- The Austin Strategic Housing Blueprint is another initiative which identifies potential regulations, funding mechanisms, and other approaches that the City should employ to achieve housing goals. The blueprint outlines community values and serves to facilitate community partnerships and align resources. The blueprint is closely aligned the Austin's comprehensive plan and serves as a strategic guide for the achievement of affordable housing goals [16]. 
- In 2003, the Austin Housing Coalition was founded to promote affordable housing through partnerships between nonprofit agencies, the public and private sector. In addition, the City of Austin regularly works with Community Housing and Development Organizations (CHDOs), which are non-profit affordable housing organizations. These organizations receive certified government funds for the provision of affordable housing [17].

- Since 2013, Austin has successfully passed two affordable housing bonds; one for $\$ 65$ million (2013) and another for \$250 million (2018). According to the City, the first bond resulted in 2,486 affordable housing units. Approximately $20 \%$ of the funds supported low-income and other vulnerable populations with homeowner repairs and mortgage down payment assistance; more than half of funds went towards the construction and preservation of affordable housing [18]. The most recently approved bond funnels $\$ 100$ million for affordable housing land acquisition, \$28 million for the homeownership program, \$28 million for home rehabilitation and repairs, and $\$ 98$ million for rental housing development assistance [19].

- A recent addition to Austin's affordable housing initiatives is the Affordable Housing Unlocked Program, which launched in 2019. The program was created to capitalize on the recently approved \$250 million Affordable Housing Bond and aid the City in its goal of building 60,000 affordable housing units by 2027 . The program provides aggressive density bonuses, height increases, offers waivers, and loosens zoning restrictions for developers providing at least $50 \%$ affordable housing in new developments [20]; a key stipulation is that units must be affordable for 99 years. The program is extremely progressive, allowing for the waiver of compatibility requirements such as height restrictions and setbacks, allowing for developers to maximize density [21].

- Finally, housing land trusts have played an important role in workforce housing development. Any new workforce housing programs should be coupled with a mechanism to ensure that housing remains affordable in perpetuity or for 99 years. The community land trust model is an extremely attractive mechanism for maintaining and expanding the stock of affordable housing. Currently there are approximately 160 community land trusts operating in every region of the country. These community land trusts are nonprofit, community-based organizations whose mission is to provide affordable housing in perpetuity by owning land and leasing it to those who live in houses built on that land. In the classic community land trust model, membership is comprised of those who live in the leased housing (leaseholders); those who live in the targeted area (community members); and local representatives from government, funding agencies and the nonprofit sector (public interest). Land trusts can be used for ownership or lease projects. A community land trust also includes a resale formula intended to balance the interests of present homeowners with the long-term goals of the community land trust - to provide affordable housing for future homeowners. With this model, a homeowner can see an appreciation of their equity of approximately $\$ 2,500$ per year but when the time comes to sell the house/condo, the unit is still at an affordable housing price relative to the year they bought it.

\section{CASE STUDY}

One homeownership model that has recently been developed in East Austin is The Chicon - a three story, mixed-use development in two buildings (Fig. 1). All but six of the 
33 residential units were purchased by households making less than $80 \%$ of the Austin Area Median Family Income $(\$ 44,000 /$ year in 2010 , but now $\$ 53,000 /$ year. As an example, these annual salaries are equivalent to a starting salary for teacher, firefighter or police officer).

The residential units in The Chicon range in size from 650-1200 sf. The affordable units sold from $\$ 145,000-\$ 245,000$. In contrast, the market-rate units sold from $\$ 175,000-\$ 340,000$. The main issue that potential buyers had was larger units were more challenging to afford, given their income restrictions. Phase One of The Chicon was successful - it has been 6 months since the last homebuyer moved in. The entire cost of this project was $\$ 11,750,000$.

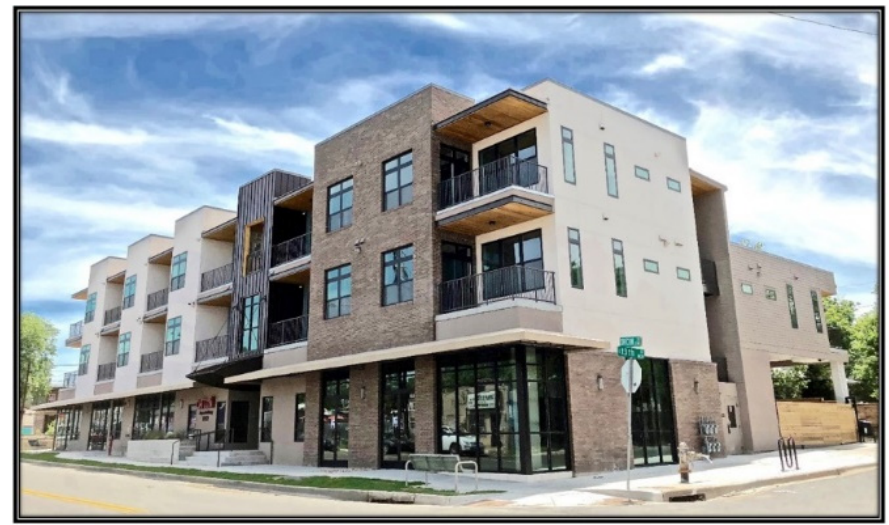

Figure 1: Phase one of The Chicon in Austin, TX.

Phase Two of the Chicon is just now being planned (Fig. 2). The developer - a non-profit CHDO called Chestnut Revitalization Corporation (CNRC) has decided to develop Phase Two under the Affordable Housing Unlocked Ordinance. By so doing, Phase Two will consist of 49 residential units, versus the 15 units that could have previously been developed. This new ordinance also removes parking requirements - thereby reducing the costs significantly. The preliminary cost of this building is $\$ 6,000,000$. With smaller units $(500-$ $850 \mathrm{sf}$ ) the price of ownership is smaller, and the market demand is broader.

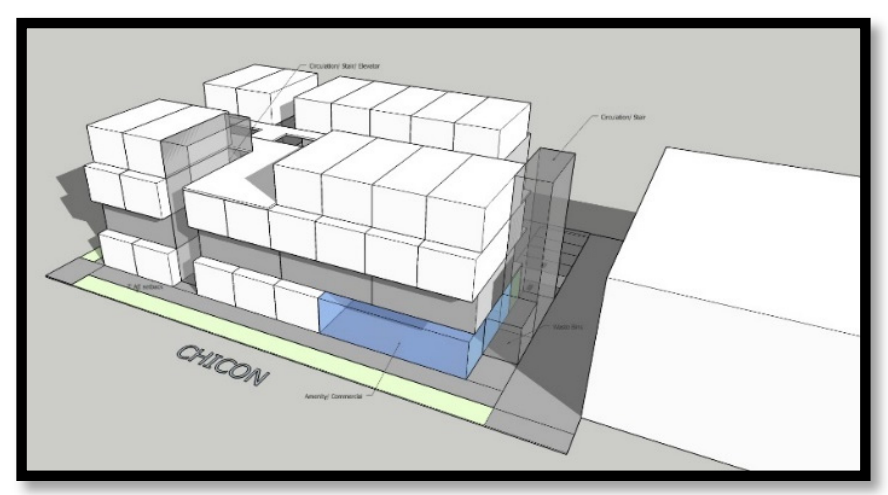

Figure 2: Rendering of phase two of The Chicon. 


\section{CONCLUSION}

Given Spain's high homeownership rate (versus rental), perhaps the Tax Credit program described above could help stimulate additional rental housing. Yet, the main crux of this article is how Spain could adapt other homeownership programs as Austin, Texas and The Chicon project employed. While affordable housing continues to be a challenge in Austin, the range of new initiatives shows promise and a desire to address the local housing issues.

Most large urban cities have high price increases on their land and housing costs, due to a finite amount of land to develop. As population continues to increase, the value of land per person becomes exorbitant, as the Silicon Valley case above illustrates. In addition, in revitalizing areas (like East Austin, which experienced the $3^{\text {rd }}$ fastest rate of gentrification in the US in 2010-2015), the level of displacement can be extreme, due to rising market interests in the revitalized area and subsequent rapid land and home price escalation.

Several cities have adopted workforce housing programs that create and preserve affordable housing, including efforts such as grants or no-interest loans. As Spain (and other European countries) continue to face affordable housing challenges, the implementation of a targeted plan, with addition mechanisms for the provision and preservation of affordable housing, may prove crucial for addressing the diverse housing needs of all workers and residents.

\section{REFERENCES}

[1] Kalugina, A., Affordable housing policies: An overview. Cornell Real Estate Review, pp. 78-79, 2016.

[2] U.S. Department of Housing and Urban Development, Low-income housing tax credits. www.huduser.gov/portal/datasets/lihtc.html. Accessed on: 28 Jul. 2019.

[3] Center on Budget and Policy Priorities, Housing choice voucher fact sheets. www.cbpp.org/housing-choice-voucher-fact-sheets. Accessed on: 28 Jul. 2019.

[4] Jones, J., Spain: A nation where two-thirds of population are flat-dwellers, The Local, www.thelocal.es/20151127/spain-the-nation-with-the-most-flat-dwellers-in-europe.

Accessed on: 28 Jul. 2019.

[5] White, T., Spain is latest battleground for global affordable housing, Bloomberg. www.bloomberg.com/markets/fixed-income. Accessed on: 28 Jul. 2019.

[6] O'Sullivan, F., Barcelona forces banks to turn repossessed homes into affordable housing, City Lab. www.citylab.com/equity/2018/04/barcelona-is-taking-overrepossessed-homes/558239/. Accessed on: 28 Jul. 2019.

[7] Sun, K., Spain's socialist government hits apartment landlords with rent cap, real deal. https://therealdeal.com/2019/03/16/spains-socialist-government-hits-apartmentlandlords-with-rent-cap/. Accessed on: 28 Jul. 2019.

[8] Housing Europe, Housing cost overburden rate in the EU. www.housingeurope.eu/blog-566/housing-cost-overburden-rate-in-the-eu. Accessed on: 28 Jul. 2019.

[9] Brinklow, A., Silicon Valley has the highest housing costs in the U.S., Curbed San Francisco. https://sf.curbed.com/2019/2/19/18229922/silicon-valley-index-2019housing-gentrification-wealth-gap. Accessed on: 28 Jul. 2019.

[10] Silicon Valley Institute for Regional Studies, Silicon Valley indicators. https://siliconvalleyindicators.org/data/economy/income/household-income/medianhousehold-income/. Accessed on: 28 Jul. 2019.

[11] Department of Numbers, US household income.

www.deptofnumbers.com/income/us/. Accessed on: 28 Jul. 2019. 
[12] Silicon Valley at Home, Housing affordability. https://siliconvalleyathome.org/resource-map/housing-affordability/. Accessed on: 28 Jul. 2019.

[13] Silicon Valley Community Foundation, Silicon Valley's housing crisis: How did we get here, and what can we do about it? www.siliconvalleycf.org/sites/default/files/publications/housing-brief-spring.pdf. Accessed on: 28 Jul. 2019.

[14] Hedman, C., Elliot, D., Srini, T. \& Kooragayala, S., Austin and the state of low- and middle-income housing. Urban Institute, p. v, 2017.

[15] Neighborhood Housing and Community Development, SMART housing policy resource guide.

file://C:/Users/Cathy/Desktop/Conf\%20Paper\%202/smart_guide_0708.pdf. Accessed on: 28 Jul. 2019.

[16] Neighborhood Housing and Community Development., Austin strategic housing blueprint.

file://C:/Users/Cathy/Desktop/Conf\%20Paper\%202/Strategic_Housing_Blueprint_4. 24.17 reduced_pdf. Accessed on: 28 Jul. 2019.

[17] HUD Exchange, Home CHDO. www.hudexchange.info/programs/home/topics/ chdo/\#policy-guidance-and-faqs. Accessed on: 28 Jul. 2019.

[18] City of Austin, General obligation bond return on investment. www.austintexas.gov/ department/return-on-investment. Accessed on: 28 Jul. 2019.

[19] Salazar, D., 2018 Election: \$250M affordable housing bond heartily endorsed. www.bizjournals.com/austin/news/2018/11/07/2018-election-250m-affordablehousing-bond.html. Accessed on: 28 Jul. 2019.

[20] Widner, C., Did Austin just unlock affordability? Austin Curbed. https://austin.curbed.com/2019/5/13/18618370/affordable-housing-austin-densityzoning-plan. Accessed on: 28 Jul. 2019.

[21] City of Austin, Affordability unlocked development bonus program. www.austintexas.gov/department/affordability-unlocked. Accessed on: 28 Jul. 2019. 